\title{
Valuation of Environmental and Social Functions of the Multifunctional Cypriot Agriculture
}

\author{
Athanasios Ragkos ${ }^{1}$, Alexandros Theodoridis ${ }^{2}$ \\ ${ }^{1}$ Department of Rural Development and Agribusiness Management, Alexander Technology \\ Educational Institute of Thessaloniki, Greece, e-mail: tragos@agro.auth.gr \\ ${ }^{2}$ School of Veterinary Medicine, Aristotle University of Thessaloniki, e-mail: \\ theoagrecon@mail.com
}

\begin{abstract}
The multifunctional farm sector in Cyprus poses threats on the island's water resources, but also highly contributes to preserving the cultural identity, incomes and employment in rural areas. This paper presents an application of the Choice Experiment method, in order to evaluate these features of Cypriot agriculture, which are externalities, as farmers are not remunerated in markets for such services. The results of the empirical analysis demonstrate that the Cypriot public is in favor of a less intensive pattern of agriculture. Furthermore, Cypriots are willing to pay in order to mitigate adverse environmental effects of agriculture, to improve cultural heritage and to safeguard the continuation of farming trade on the island. The estimated benefits often exceed income losses from changes in the cropping pattern, which verifies that EU rural development policies are regarded as beneficial by the public.
\end{abstract}

Keywords: Multifunctionality, Choice Experiment, Rural development, Cyprus

\section{Introduction}

The agricultural sector is multifunctional, given its complex interactions with the environment and rural amenities. Agriculture's multifunctionality has been a central issue during trade liberalization negotiations in WTO and is steadily gaining attention in the agricultural policy agenda. Proponents of multifunctionality claim that the maintenance of rural landscapes, the viability of rural areas and food security are some of the non-traded outputs of agriculture, which are endowed with public good characteristics or are externalities (OECD, 2001). As such, these non-traded outputs provide additional arguments in favor of intervention in the farming sector.

The debate over agriculture's multifunctionality has been mainly based on societal perceptions of values that stem from agricultural activity. Farmers continue to provide society with landscapes and keep rural economies viable but they are not rewarded by markets. A positive approach of multifunctionality recognizes multiple functions of agriculture, but favors policy measures to arrange their provision as long as they are perceived and valued by society (Vermersch, 2001, Allaire and Dupeuble, 2002, OECD, 2003). If society is not affected by non-traded outputs of agriculture, there is no room for public intervention. Therefore, central to the use of BBBBBBBBBBBBBBBBBBBBBBBBBBBBBBBBBBB

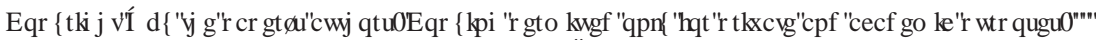

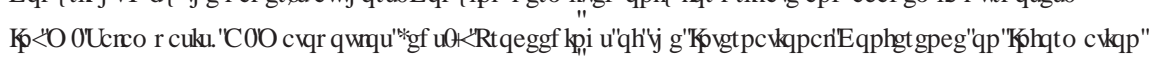
DQGH\&RP P XQLFDURQQ7 HFKQRQRJ IHMIII (1)

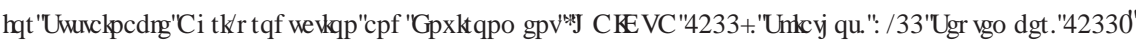


multifunctionality in the agricultural policy reform agenda is to provide estimates of the values of non-traded outputs, which sum up to the total economic value of agriculture (Hediger and Lehmann, 2003).

The multifunctional character of agriculture is an emerging issue in academic circles. Many authors have examined the effects of price policies on the production of non-traded outputs (Randall, 2002, Peterson et al., 2002, Romstad, 2004a, b), the implications of joint production of traded and non-traded outputs (Paarlberg et al., 2002, Havlik et al., 2005) and the possibilities of valuing agriculture's externalities (Boody et al., 2005). The valuation of multifunctional aspects of agriculture, on continent scale, has been highlighted by Randall (2002). Stated preference techniques, such as Contingent Valuation (CV) and Choice Experiments (CE), have been employed in order to attach monetary values to non-traded outputs of agriculture (Yrjola and Kola, 2004, Kallas et al., 2007).

The purpose of this paper is to provide estimates of the value that society places on certain features of multifunctional agriculture. The CE method is employed in order to examine the factors that affect individual preferences about functions of multifunctional agriculture and then estimate monetary values for these functions. The experimental design considers four attributes. The first two functions concern the adverse environmental effects of agriculture; that is pollution of water resources by pesticide and fertilizer use and pressures on water reserves from irrigation. The third function is related to the preservation of cultural heritage and rural landscapes, which formulate the identity of rural regions on the island. The fourth function is the maintenance of the farming trade, which is multifunctional; it is expected that the public is positively predisposed towards farmers.

The CE data are analyzed by estimating a Conditional Logit Model (CE) and Random Parameters Logit Models (RPL), which are based on Random Utility Models (RUM). The estimated coefficients reveal public preferences towards the valued function of agriculture and focus on the effects of particular characteristics on the acceptance of changes in the provision of agriculture's externalities. Furthermore, these coefficients are used in the estimation of the Marginal Willingness to Pay (MWTP) for the valued functions. As a final step, income losses from changes in the cropping pattern are compared to benefits from non-traded outputs of the Cypriot agriculture; the results reveal a net social surplus from the adoption of an extensive cropping pattern, due to the provision of externalities at the level that society desires.

\section{Agriculture's Multifunctionality in the Policy Agenda}

Agriculture's multifunctionality reflects the fact that the agricultural sector jointly produces non-traded outputs, food and fiber. The former, referred to as "nontrade concerns" in the WTO agenda, are often externalities or are endowed with public good characteristics. Although controversial, the concept of agriculture's multifunctionality has been central among countries' claims of widening the "green box" measures in order to protect unique farming systems that produce some of these externalitites. It is worth to notice that the negative externalities of agriculture, such as pressures on water resources and air quality, have been long recognized in literature (see Pretty et al., 2000); however, the concept of multifunctionality in agricultural policy reform has focused on positive externalities on employment, income, cultural heritage and rural development. 
The EU farm sector has been long recognized as multifunctional, as is expressed by small family farms that prevail in the Continent (de Vries, 2000). This "European Model of Agriculture" plays a significant role in maintaining vivid rural areas and protecting the environment and cultural heritage (Casini et al., 2004). EU policies favor protectionism in the farm sector, as market competition could abolish this model of agriculture. The Common Agricultural Policy (CAP) provides economic incentives, many of which have influenced non-traded farm outputs. However, these measures did not achieve environmental and rural development goals. Regulations (EC) $1782 / 2003$, (EC) 73/2009 and (EC) 864/2004 and (EC) 1698/2005 recognize that farming should always safeguard soil quality and protect the environment.

The relationships between agriculture and the environment are predominantly complex. The extent to which farming affects the environment, either positively or negatively, depends on input use and on the cropping pattern. Conventional farming systems in the EU produce negative environmental externalities which affect soil, air quality and surface and ground water resources. The main pressures of agriculture on water resources and aquatic ecosystems are due to poor management of irrigation and non-point sources of pollution, mainly residuals of agrochemicals (Hitchens et al., 1978, Thampapillai and Sinden, 1979, Burton $\kappa a l$ Martin, 1987, Pretty et al., 2000).

Lately, agroenvironmental policy measures have emerged in order to minimize adverse environmental effects of agriculture (Dobbs and Pretty, 2004). The recent CAP reform introduced payments to farmers who adopt integrated or organic farming and incentives to expand fallow lands and forests (Axis II, Reg. (EU) 1698/2005).

Another category of agriculture's externalities is the formulation of agricultural landscapes (Lindland, 1998, Peterson et al., 2002, Casini et al., 2004). These landscapes include both natural and man-made elements which reflect structural changes in the sector as well as social, cultural and political changes that occurred during centuries. It is argued that rural landscapes characterize and differentiate the countryside and they constitute development resources for these areas.

Agriculture's role in rural development is undeniably significant. Functions such as safeguarding rural populations, protecting cultural heritage and maintaining the farming trade are some of its non-traded outputs that affect rural amenities. Farm policies are considered necessary in maintaining them; however, it is ambiguous that market interventions are the ideal measures to induce rural development. Most countries agree that the diversification of rural economies is prerequisite for lively rural areas. This trend is reflected in the constant emergence of pluriactive farms in the Union (Potter, 2004). It is argued, however, that in regions where the rural economy is poorly diversified, such as EU's LFAs, agriculture performs cultural and environmental functions, except for its predominant role in local economy and employment. The introduction of EU Reg. 1698/2005 depicts the incorporation of such issues in the CAP, and acknowledges that basic infrastructure is necessary to retain acceptable population levels, rather than a heavily subsidized primary sector.

Cultural heritage and the mere identity of rural regions have been shaped, throughout the years, by the predominance of agriculture. The countryside is endowed with a wide range of cultural features, such as traditions, music, dances and architecture. These elements differ among regions and constitute resources that support rural development, based on existing advantages (Lowe et al., 2002, Jervell and Jolly, 2003). The public perceives farmers as the keepers of this "agricultural 
cultural heritage" (Abler, 2003), thus recognizing concrete links between farming and culture. Nevertheless, markets often fail to remunerate farmers for these services.

Farming has traditionally been viewed by society as a particular trade, as life in the countryside and constant interactions with nature are unique to the profession. The multifunctional character of agriculture impels farmers to redefine their scopes in order to integrate them in a modern framework which embraces economic, environmental and social aspirations (Deverre, 2002). Cayre et al. (2004) recognize social and ethical motivations in engaging with farming. Non-economic motivations are reflected in the maintenance of small family farms with poor economic performance, as well as in pluriactive farmers, who take over other activities in order to subsidize the continuation of farming (Streeter, 1988, Sumner, 1991).

According to Harvey (2003) the positive way in which society regards farming stems from the development process during the industrial revolution, of which farmers are the "losers", who did not have the opportunity to move from the countryside and seek new forms of employment and a modern way of life in urban areas. The "winners" of this process, civilians, retain a "romantic" view for farmers. Within this context, the CAP recognized farmers as a disadvantaged trade even from its origins (Potter and Burney, 2002).

\section{The Farming Sector in Cyprus}

The main environmental problem in Cyprus is water management. Low annual rainfalls threaten surface and ground water reserves on the island. Given that the farming sector accounts for $70 \%$ of the total water consumption in Cyprus, irrigation policies are of vital importance not only for the farming sector, but also for the economy as a whole.

Water reserves are also threatened by agrochemical use. The expansion of irrigated crops (potatoes, citrus, olives and grapes) has resulted in a considerable increase in the use of fertilizers and pesticides, whose residuals pollute the otherwise limited water resources on the island. Especially nitrogen pollution is severe and is the main cause of eutrophication.

During the last 25 years, the Cypriot government has prioritized the implementation of integrated irrigation water management policies. An estimated $80 \%$ of total funding of the Ministry of Agriculture, Natural Resources and the Environment has been directed to irrigation projects. Nowadays, $23 \%$ of total farmland is irrigated. The amelioration of irrigation networks has permitted the extensive introduction of Improved Irrigation Systems, which nowadays cover approximately $95 \%$ of the irrigated farmland and have brought about water savings of up to $70 \mathrm{mil} . \mathrm{m}^{3} /$ year. Nevertheless, continuous droughts in the past few years have deteriorated salinization and have intensified pressures on water reserves, with considerable adverse effects on ecosystems and biodiversity.

The Cypriot farming sector contributed by $3,1 \%$ to the GDP and by 6,7 to employment in 2008. However, its contribution is vital in incomes and employment in highland rural areas, where tourism and manufacturing activities are limited. Features of agricultural cultural heritage are widespread in rural areas of the island, including monuments, festivals, museums and buildings (windmills, bridges, oil mills etc). The importance of these cultural resources has been recognized and considerable efforts are in force in order to incorporate them into rural development 
strategies. The Rural Development Program, in force since 2007, endorses investments and actions to protect cultural features through measure 3.2, in order to prevent depopulation of rural areas.

\section{Methodological Framework}

The effects of agriculture's externalities are difficult to value, as they are not captured by the production functions. Stated preference valuation techniques have been applied by numerous authors during the past few years, in order to attach monetary values to non-marketed goods and services (Lusk et al., 2003, Birol et al., 2006, Travisi and Nijkamp, 2008, Christensen et al., 2011). Among stated preference techniques, this paper adopts the Choice Experiment (CE) approach to value agricultural externalities.

The CE method is based on Lancaster's (1966) theory of consumer preference, according to which goods and services can be described in terms of their characteristics. The design of a choice experiment requires the choice of attributes that describe the good of service as well as the determination of levels for each attribute. The researcher adds a monetary attribute that corresponds to an amount that a member of a hypothetical market would be willing to pay in order to achieve the attribute levels they desire. The possible combinations of attributes and levels yield the alternatives, which are then organized in pairs in order to formulate the choice sets. Each respondent is presented with 4-16 choice sets (Louviere et al., 2000) and for each one they are asked to mark the alternative they prefer.

The econometric analysis of CE data is based on Random Utility Models where utility is distinguished in an observed $\left(\mathrm{V}_{\mathrm{ij}}\right)$ and an unobserved $\left(\varepsilon_{\mathrm{ij}}\right)$ part.

$$
U_{i j}=V_{i j}+\varepsilon_{i j}
$$

Based on RUM, several econometric models have been proposed for the analysis of choice data, among which Conditional Logit (CL) models (McFadden, 1973) have been widely applied. In CL models, the indirect utility function is linear and the stochastic component of the utility is Gumbel extreme Type-B independently and identically distributed. The probability distribution function is formulated as follows, where the probability (denoted $\mathrm{P}_{\mathrm{ij}}$ ) of respondent $\mathrm{i}$ choosing alternative $\mathrm{j}$ over all other $\mathrm{k}$ alternatives in choice set $\mathrm{B}$ equals the utility from this alternative over the utility from all other alternatives.

$$
P_{i j}=\frac{e^{\mu V_{i j}}}{\sum_{k=1}^{J} e^{\mu V_{i k}}} \forall j, k \in B
$$

The basic CL model is subject to two limitations. The first is the Independence of Irrelevant Alternatives (IIA) property, which states that the choice probability between two alternatives is not influenced by the inclusion or exclusion of other alternatives in a choice set. If IIA does not hold, the model might be biased (Christiardi and Cushing, 2007). Second, this CL model does not account for preference heterogeneity. This can be arranged in two ways. Observed (systematic) heterogeneity can be captured in respondents' social and economic characteristics, 
which enter the model as interaction terms. Unobserved heterogeneity is captured in the random part of the RUM.

Random Parameters Logit models (RPL) (Revelt and Train, 1998) are similar to CL in that they are based on the same distributional and behavioural grounds. However, in RPL models a separate linear utility function is introduced for each respondent and standard deviations for random coefficients account for unobserved heterogeneity; hence, utility from choosing an alternative in a choice set is itself a random variable. The probability distribution function is formulated as follows, where $\eta_{\mathrm{i}}$ is the random factor in the utility function.

$$
P_{i j}=\frac{e^{Z_{i j}\left(\beta+\eta_{i}\right)}}{\sum_{k=1}^{J} e^{Z_{i k}\left(\beta+\eta_{i}\right)}} \forall j, k \in B
$$

Formula (3) can be solved by simulation, using the simulated maximum likelihood estimation (Train, 2003). For the estimation, Halton draws are preferred, in order to minimize variance (Bhat, 1999, 2000). The choice of random coefficients and distributional forms depends on the researcher. Hensher et al. (2005) argue in favor of a normal distribution, while Revelt and Train (1998), Lusk et al. (2003) and Morey and Rossman (2003) assumed normal distributions in their analyses.

Following the results of the estimation of logit models, welfare measures can be estimated for each attribute. The monetary value of the good or service under consideration is reflected in the compensating surplus (CS) (Hicks, 1939, Hanemann, 1984), using formula (4) (Hanemann, 1989).

$$
C S=\frac{\ln \sum_{i=1}^{I} e^{V_{i 1}}-\ln \sum_{i=1}^{I} e^{V_{i 0}}}{\beta_{\text {payment }}}
$$

where $\mathrm{V}_{\mathrm{i} 0} \kappa \alpha \mathrm{l} \mathrm{V}_{\mathrm{i} 1}$ are utilities of individual i before (status quo situation) and after the implementation of the proposed management scenario and $\beta_{\text {payment }}$ is the coefficient of the monetary attribute, which stands for the marginal value of income.

The most commonly used welfare measure in non-market valuation is Willingness to Pay (WTP). In choice experiments, the experimental design allows for the estimation of the Marginal Willingness to Pay (MWTP), for marginal changes in the level of each attribute, as the trade-off between income and a marginal change in the level of the attribute. For CL models, as well as for attributes with fixed coefficients in RPL models, trade-offs are estimated by means of formula (5)

$$
M W T P=-\frac{\beta_{\text {attribute }}+\beta_{1} S_{1}+\ldots+\beta_{n} S_{n}}{\beta_{\text {payment }}}
$$

where $\beta_{1} \ldots \beta_{n}$ are the coefficients of interaction terms $S_{1} \ldots S_{n}$. It is obvious that formula (5) takes into account the observed part of preference heterogeneity.

MWTP for random coefficients in RPL models is estimated using the formula (5); however, in order to take into account the standard deviations, Hensher et al. (2005) describe a technique that uses the population minutes, in order to simulate the unknown distribution of MWTP. By simulating the distribution, it is possible to 
estimate means, medians and standard deviations, depending on the distributional assumptions about the random coefficients (Abou-Ali and Carlsson, 2004).

Confidence intervals for MWTP are estimated using bootstrapping techniques, in order to simulate unknown and complex distributions. Krinsky and Robb (1986) proposed a method which uses random draws from a multivariate normal distribution, using the vector of estimated coefficients and the estimated variancecovariance matrix. For random coefficients, the procedure uses population minutes. In both cases, MWTP is estimated for each draw and the resulting welfare measures create the unknown distribution.

\section{Survey Design and Administration}

The CE questionnaire includes three parts, following common recommendations in literature (Mitchell and Carson, 1989, Arrow et al., 1993, Boxall et al., 1996). In the first part, respondents are asked about their attitudes towards multifunctionality, using Likert-scale questions; in the third part respondents' social, economic and behavioral characteristics are recorded.

The second part of the questionnaire starts with a brief explanation of externatilies that affect the environment and society, as well as relevant problems. As a solution, a change in the cropping pattern is proposed. The introduction of an agroenvironmental, non-government trust-fund is proposed, which will be in charge of actions and synergies necessary to carry out changes in the cropping pattern. Individuals who are interested in this management scenario are invited to volunteer by paying an amount to the trust-fund. This payment vehicle is considered compatible to the nature of the proposed trust-fund, as such bodies could perform better in organizing efforts, by taking into account particularities at the local level (Blandford and Boisvert, 2002). Dwyer and Hodge (1996) are also in favor, following the example of carts operating in the UK.

The payment scenario is based on the results of a mathematical programming analysis (details are available in Ragkos et al., 2010). Using published technical and economic indicators of the main crops in Cyprus, a parametric programming model yielded 15 alternative cropping patterns for the country, each subsequent of which represents reduced requirements in input use. The basic characteristic of this change is the predominance of wheat, which gradually substitutes tree crops and vegetables, thus reducing the use of agrochemical inputs and irrigation water. Nevertheless, this shift to wheat brings about a loss in farm jobs, due to its low requirements in human labor, and a raise in incomes per farmer, as the loss in total revenue would be counterbalanced by the reduction of the number of farmers. The main results of the 15 cropping patterns are presented in Table 5.

The design of the CE survey was based on the results of the parametric programming model. The five attributes included in the experimental design are (see also Table 1):

1. "Reduction in agrochemical use". This attribute captures respondents' preferences about environmental externalities of agriculture, considering the adverse effects of detrimental inputs on the environment.

2. "Reduction in water consumption". The consideration of public preferences towards irrigation water could inform water management policies. 
3. "Rural development and cultural heritage". This attribute involves retraining farmers who will leave farming, as a result of changes in the cropping pattern, in order to engage in other sectors of the rural economy. It reflects the values of rural cultural heritage and rural landscapes.

4. "Increase in incomes from agriculture". An increase in farm incomes induces farmers to remain in the trade. Preferences towards this attribute reflect public interest in safekeeping the farming sector and imply the degree of consent for maintaining protectionism in the sector.

5. "Payment" is the amount of money that a respondent would pay by choosing an alternative.

Table 1. Attributes and levels in the CE design

\begin{tabular}{|c|c|c|}
\hline Attributes & Levels & Description \\
\hline $\begin{array}{l}\text { Reduction in } \\
\text { agrochemical use }\end{array}$ & $\begin{array}{l}11 \%, 34 \% \\
46 \%\end{array}$ & $\begin{array}{l}\text { Reduction in the value of pesticides and fertilizers } \\
\text { used as a result of changes in the cropping pattern }\end{array}$ \\
\hline $\begin{array}{l}\text { Reduction in water } \\
\text { consumption }\end{array}$ & $\begin{array}{l}16 \%, 41 \% \\
60 \%\end{array}$ & $\begin{array}{l}\text { Reduction in irrigation water consumption as a result } \\
\text { of changes in the cropping pattern }\end{array}$ \\
\hline $\begin{array}{l}\text { Rural development } \\
\text { and cultural heritage }\end{array}$ & $\begin{array}{l}18.571 \text { farmers } \\
24.910 \text { farmers } \\
27.852 \text { farmers }\end{array}$ & $\begin{array}{l}\text { Number of farmers who leave farming, as a result of } \\
\text { changes in the cropping pattern, and will be retrained } \\
\text { in other sectors of the rural economy (development } \\
\text { of rural landscapes and rural cultural heritage) }\end{array}$ \\
\hline $\begin{array}{l}\text { Increase in incomes } \\
\text { from agriculture }\end{array}$ & $\begin{array}{l}18 \%, 25 \% \\
37 \%, 45 \%\end{array}$ & $\begin{array}{l}\text { Increase in incomes per farmer as a result from } \\
\text { changes in the cropping pattern, which entail less } \\
\text { employment in the sector }\end{array}$ \\
\hline Payment & $\begin{array}{l}30 €, 80 €, 150 €, \\
350 €, 500 €\end{array}$ & Amount of money paid for each alternative \\
\hline
\end{tabular}

The full-factorial yielded 540 alternatives, which were reduced to 25 , using the orthogonal design command in the statistic package SPSS 17.0. The 25 remaining alternatives were organized in 25 choice sets, which were then divided into four groups, three of six alternatives and one of seven. This process yielded four different versions of the questionnaire. Each respondent was presented with one version, therefore making six or seven choices.

The sampled population consisted of the total adult population in the Republic of Cyprus. The stratified random sampling method yielded a sample of 407 respondents. Enumerators approached all respondents and the response rate was very high (81\%), which finally produced a total of 330 valid questionnaires. After removing protest votes (see a discussion in Arrow et al. (1993)), a total of 1558 choices was used for the analysis.

\section{Empirical Results}

Responses to the Likert-scale questions in $1^{\text {st }}$ part of the questionnaire were analyzed and five multiple-item indexes were formulated, which represent respondents' attitudes towards specific aspects of multifunctionality of agriculture in Cyprus. These indexes are explained in Table 2, along with other variables in the analysis. 
The results of the maximum likelihood estimation of the CL model are reported in the first column of Table 3. All coefficients are significant at the $1 \%$ level, which indicates that all attributes are important explanatory factors of preferences towards multifunctionality. The positive signs of "Agrochemicals", "Water", Retrain" and "Farm_Income" reveal that the probability that a respondent chooses an alternative is increased by an increase in their levels, while, as expected, the opposite holds for an increase in "Amount".

The CL model was tested for the IIA using the Hausman - McFadden (1984) test. The null-hypothesis that IIA does not hold cannot be rejected when Alternatives $\mathrm{B}$ or $\mathrm{C}$ are removed. This entails that the results of the estimation are biased, therefore RPL models are estimated.

Table 2. Variables used in the empirical analysis

\begin{tabular}{ll}
\hline Variables & Description \\
\hline Agrochemicals & Attribute "Reduction in agrochemical use" \\
Water & Attribute "Reduction in water consumption" \\
Retrain & Attribute "Rural development and cultural heritage" \\
Farm_Income & Attribute "Increase in incomes from agriculture" \\
Payment & Attribute "Payment" \\
Gender & Male/Female \\
Age & Numeric variable \\
Income & Ordinal variable \\
Education & Numeric variable (Years of schooling) \\
Resident & Lives/Does not live in a rural area \\
Farm_Family & Comes/Does not come from a farm family \\
Rural_Family & Has grown/Has not grown up in a rural area \\
Env_Group & Membership in an environmental club \\
Knowledge & Latent variable - Knowledge about multifunctionality \\
Water_Management & Latent variable - Attitude towards water use \\
Environment & Latent variable - Environmental consciousness \\
Cult_Her & Latent variable - Attitudes towards agricultural culrutal heritage \\
Farming & Latent variable - Attitudes towards the farming trade \\
\hline
\end{tabular}

The RPL model is reported in the second column of Table 3. "Water" and "Payment" are normally distributed random coefficients. All coefficients are significant at the $1 \%$ level and of the expected sign; hence, an increase in the level of non-monetary attributes affects utility positively, whereas larger payments reduce the level of utility. The latter finding was expected, due to income constraints. 
Table 3. Conditional Logit and Random Parameters Logit models

\begin{tabular}{|c|c|c|c|}
\hline Variables & $\begin{array}{l}\text { Conditional logit } \\
\text { (CL) }\end{array}$ & $\begin{array}{c}\text { Random } \\
\text { Parameters Logit } \\
\text { (RPL) }\end{array}$ & $\begin{array}{c}\text { Random } \\
\text { Parameters Logit } \\
\text { with interactions } \\
\text { (RPL-INT) }\end{array}$ \\
\hline Intercept & $\begin{array}{l}-2,48927^{* * *} \\
(0,35727)\end{array}$ & $\begin{array}{l}-2,11162^{* * *} \\
(0,47357)\end{array}$ & $\begin{array}{c}-2,48527^{\star \star \star} \\
(0,47647)\end{array}$ \\
\hline Agrochemicals & $\begin{array}{l}0,01883^{* * *} \\
(0,00363)\end{array}$ & $\begin{array}{c}0,02879^{* * *} \\
(0,00641)\end{array}$ & \\
\hline Water & $\begin{array}{c}0,02674^{* * *} \\
(0,00264)\end{array}$ & $\begin{array}{l}0,03165^{\star * *} \\
(0,00438)^{a}\end{array}$ & $\begin{array}{c}-0,10711^{* * *} \\
(0,03842)^{a}\end{array}$ \\
\hline Retrain & $\begin{array}{l}0,5177^{*} 10^{\wedge}-4^{\star \star *} \\
\left(0,1394^{*} 10^{\wedge}-4\right)\end{array}$ & $\begin{array}{c}0,5567^{*} 10^{\wedge}-4^{* * *} \\
\left(0,1999^{*} 10^{\wedge}-4\right)\end{array}$ & \\
\hline Farm_Income & $\begin{array}{c}0,01645^{\star \star *} \\
(0,00450)\end{array}$ & $\begin{array}{c}0,03277^{* * *} \\
(0,00782)\end{array}$ & \\
\hline Payment & $\begin{array}{c}-0,00756^{* * *} \\
(0,00040)\end{array}$ & $\begin{array}{l}-0,02331^{* * *} \\
(0,00369)^{a}\end{array}$ & $\begin{array}{c}-0,06303^{\star * *} \\
(0,01152)^{a}\end{array}$ \\
\hline Water ${ }^{\star}$ Gender & & & $\begin{array}{l}0,01333^{\star *} \\
(0,00626)\end{array}$ \\
\hline Payment*Gender & & & $\begin{array}{l}-0,00488^{* *} \\
(0,00196)\end{array}$ \\
\hline Agrochemicals*Age & & & $\begin{array}{l}0,00041^{*} \\
(0,00022)\end{array}$ \\
\hline Water*Age & & & $\begin{array}{l}0,00106^{* * *} \\
(0,00028)\end{array}$ \\
\hline Payment*Income & & & $\begin{array}{l}0,00389^{* * *} \\
(0,00093)\end{array}$ \\
\hline Water*Education & & & $\begin{array}{l}0,00589^{* * *} \\
(0,00119)\end{array}$ \\
\hline Retrain*Resident & & & $\begin{array}{c}-0,2618^{*} 10^{\wedge}-4^{* * *} \\
\left(0,0102^{*} 10^{\wedge}-4\right)\end{array}$ \\
\hline Agrochemicals*Farm_Family & & & $\begin{array}{c}0,01632 \\
(0,01019)\end{array}$ \\
\hline Farm_income*Farm_Family & & & $\begin{array}{c}-0,03678^{* * *} \\
(0,00977)\end{array}$ \\
\hline Agrochemicals*Rural_Family & & & $\begin{array}{c}-0,03701^{* * *} \\
(0,01245)\end{array}$ \\
\hline Retrain*Rural_Family & & & $\begin{array}{c}0,5901^{*} 10^{\wedge}-4^{* * *} \\
\left(0,1608^{*} 10^{\wedge}-4\right)\end{array}$ \\
\hline Water*Env_Group & & & $\begin{array}{c}-0,03032^{* * *} \\
(0,01038)\end{array}$ \\
\hline Farm_income*Knowledge & & & $\begin{array}{l}0,00225^{* * *} \\
(0,00065)\end{array}$ \\
\hline Payment*Knowledge & & & $\begin{array}{l}0,00089^{* * *} \\
(0,00022)\end{array}$ \\
\hline Water*Water_Management & & & $\begin{array}{c}0,00311^{* * *} \\
(0,00091)\end{array}$ \\
\hline Agrochemicals*Environment & & & $\begin{array}{c}0,00271^{* * *} \\
(0,00083)\end{array}$ \\
\hline Farm_income ${ }^{*}$ Cult_Her & & & $\begin{array}{l}-0,00240^{\star} \\
(0,00134)\end{array}$ \\
\hline Retrain*Cult_Her & & & $\begin{array}{c}0,1618^{*} 10^{\wedge}-5 \\
\left(0,1404^{*} 10^{\wedge}-5\right)\end{array}$ \\
\hline Farm_Income*Farming & & & $\begin{array}{c}0,00473^{* * *} \\
(0,00126)\end{array}$ \\
\hline Standard Deviations & & & \\
\hline
\end{tabular}




\begin{tabular}{l|ccc} 
Water & & $0,03379^{* * *}$ & $\begin{array}{c}0,03697^{* * *} \\
\text { Payment }\end{array}$ \\
& & $(0,01068)$ & $(0,01088)$ \\
& & $0,01411^{* * *}$ & $0,01397^{* * *}$ \\
& & $(0,00266)$ & $(0,00246)$ \\
\hline Log-Likelihood function & $-1282,955$ & $-1251,210$ & $-1079,931$ \\
McFadden $\mathbf{R}^{2}$ & 0,25045 & 0,26900 & 0,36959 \\
Draws & & 500 Halton & 1000 Halton \\
Likelihood Ratio Test & $857,366^{* * *}$ & $920,856^{* * *}$ & $1265,213^{* * *}$ \\
Observations & 1558 & 1558 & 1558 \\
\hline
\end{tabular}

* significant at the $10 \%$ level, $* *$ significant at the $5 \%$ level, $* * *$ significant at the $1 \%$ level

Note: ${ }^{\text {a }}$ denotes random parameters

Unobserved preference heterogeneity is incorporated in the standard deviations of the random coefficients, which are significant at the $1 \%$ level. The reported standard deviations indicate that changes in "Water" and "Amount" have a positive impact on utility, although its extent varies among individuals.

In order to account for both observed and unobserved preference heterogeneity, a RPL model with interaction terms (RPL-INT) was also estimated (Table 3). The random coefficients of "Water" and "Amount" are normally distributed and the estimated standard deviations are significant at the $1 \%$ level. The McFadden $R^{2}(0,36959)$ is significantly improved compared to the models without interaction terms, indicating the effects of observed preference heterogeneity. The internal validity of the model is verified by the positive sign of the interaction term "Payment*Income", which verifies that individuals of low incomes are less inclined to pay higher amounts than individuals of higher incomes. The signs of the other coefficients of the interaction terms provide indications as to the preferences of particular segments of the population.

The coefficients of the three models are used in the estimation of the marginal Willingness to Pay (MWTP) for each attribute. The estimations are based on formula (5). For random coefficients, standard deviations were taken into account.

The estimated MWTP for the non-monetary attributes are presented in Table 4. The results produced by the RPL-INT model are considered more reliable, as they incorporate all sources of preference heterogeneity. Following these, the Cypriot public are willing to pay:

1. $1,75 € /$ person for a $1 \%$ reduction in the use of agrochemicals, in order to decrease pressures on ecosystems

2. $2,16 € /$ person for a $1 \%$ reduction in the use of irrigation water

3. $1,65 € /$ person to achieve a $1 \%$ raise in the average farm incomes, which would induce farmers to remain in the trade

4. $0,0031 € /$ person in order to retrain a farmer who would leave the trade

The MWTP estimates indicate that the Cypriot public is willing to pay for the reduction of adverse environmental effects of agriculture, but also for benefits that affect society and rural development. 
Table 4. Marginal Willingness to Pay for attributes of multifunctional agriculture

\begin{tabular}{|c|c|c|c|}
\hline \multirow{2}{*}{ Attributes } & \multicolumn{3}{|c|}{$\begin{array}{l}\text { Marginal Willingness to Pay (€/person) } \\
\text { Confidence Intervals ( } 95 \%) \text { ( } € / \text { person) }\end{array}$} \\
\hline & CL & RPL & RPL-INT \\
\hline Reduction in agrochemical use & $\begin{array}{l}2,49^{* * *}(0,48)^{1} \\
(1,57)-(3,42)^{3}\end{array}$ & $\begin{array}{c}2,02^{2} \\
(-5,45)-(8,18)^{4}\end{array}$ & $\begin{array}{c}1,75^{2} \\
(0,61)-(8,63)^{4}\end{array}$ \\
\hline Reduction in water consumption & $\begin{array}{l}3,54^{* * *}(0,39)^{1} \\
(2,81)-(4,35)^{3}\end{array}$ & $\begin{array}{c}3,74^{2} \\
(-18,94)-(22,48)^{4}\end{array}$ & $\begin{array}{c}2,16^{2} \\
(-0,97)-(21,04)^{4}\end{array}$ \\
\hline Increase in incomes from agriculture & $\begin{array}{c}2,17^{* * *}(0,60)^{1} \\
(0,99)-(3,38)^{3}\end{array}$ & $\begin{array}{c}2,30^{2} \\
(-6,20)-(9,32)^{4}\end{array}$ & $\begin{array}{c}1,65^{2} \\
(0,57)-(8,13)^{4}\end{array}$ \\
\hline Rural development and cultural heritage & $\begin{array}{c}0,0068^{* * *}(0,0019)^{1} \\
(0,0033)-(0,0106)^{3}\end{array}$ & $\begin{array}{c}0,0039^{2} \\
(-0,010)-(0,016)^{4}\end{array}$ & $\begin{array}{c}0,0031^{2} \\
(0,0011)-(0,0152)^{4}\end{array}$ \\
\hline
\end{tabular}

${ }^{1}$ MWTP estimated using the WALD procedure in LIMDEP 8.0 NLOGIT 3.0. Numbers in parentheses are standard errors

${ }^{2}$ MWTP estimated using population minutes

${ }^{3}$ Numbers in parentheses denote the lower and upper confidence intervals, at the $95 \%$ level, estimated using the bootstrapping procedure by Krinsky and Robb (1986).

${ }^{4}$ Numbers in parentheses denote the lower and upper confidence intervals, at the 95\% level, estimated using population minutes

The estimated monetary values can be used for the quantification of benefits derived from the alternative cropping patterns. Each one of these scenarios corresponds to different levels of the four non-monetary attributes and, consequently, to various levels of monetary benefits from their implementation. The monetary values derived from each scenario are the compensating surpluses (CS) between the status-quo situation and the levels of these attributes in each scenario. The CS in each case is estimated using the coefficients of the RPL-INT model, which accounts for all sources of preference heterogeneity, by simulating the population minutes.

CS estimations for the 15 alternative cropping patterns are presented in Table 5. CS per person is minimized in scenario $2(-51,28 € /$ person), it increases between scenarios 3-7 and then between scenarios 9-11 and reaches a maximum at scenario $11(309,49 € /$ person). It is, therefore, evident that society attaches monetary values to the implementation of such extensive scenarios, which would entail reduced agrochemical and water use, more human resources to safeguard cultural heritage and increased farm incomes to assure the continuation of farming in Cyprus.

Losses in gross margin, due to the substitution of tree crops and vegetables by wheat, vary between $4,7 \% \kappa \alpha$ l $64,2 \%$. However, these considerable losses are counterbalanced by the total benefits, aggregated to the Cypriot population, in scenarios 3-12. The comparison between total benefits and income losses reveal a net social surplus, which varies between 19,7 mil.€ кa1 91,7 mil.€ for scenarios 12 and 5 respectively. Hence, the inclusion of the value of agriculture's externalities in the decision-making process, for example considering the introduction of an environmental-friendly policy, heavily influences the results, whether only traded outputs of agriculture are taken into account. The social and environmental impact of farming represents an important part of the total economic value of agriculture and need to be included in the decision-making process, alongside with economic criteria. 


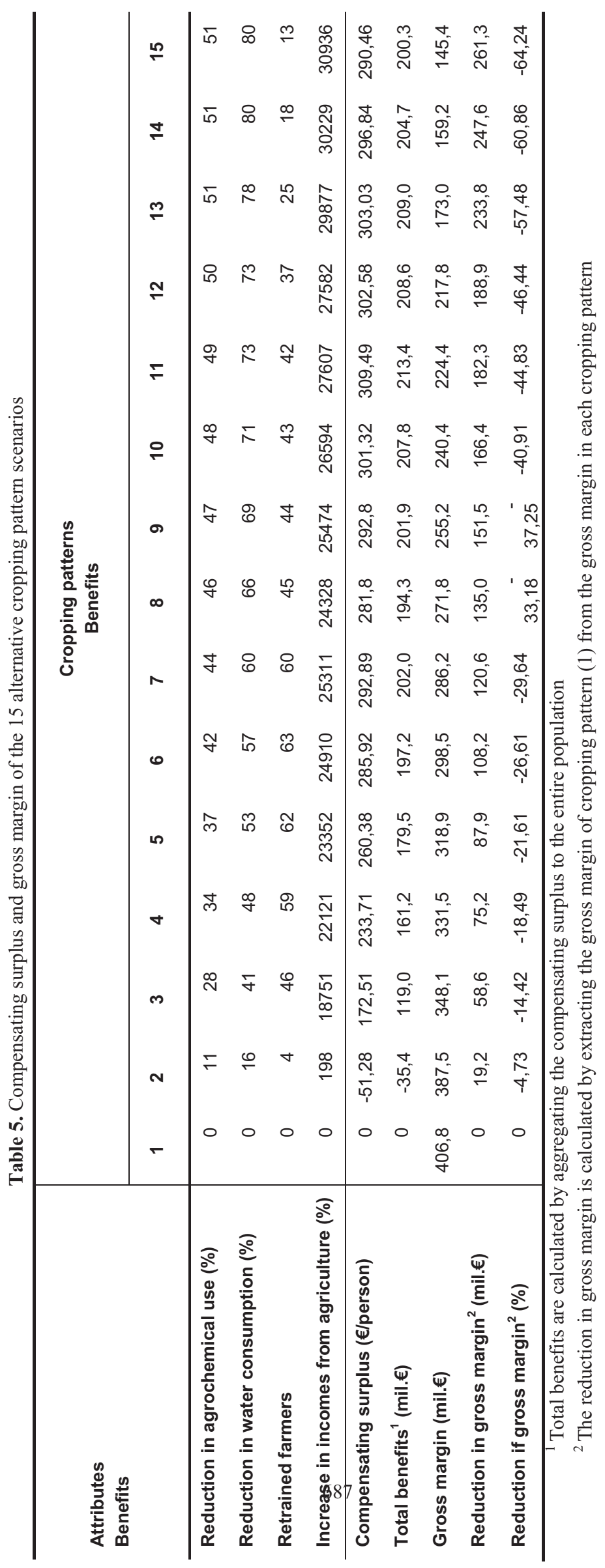




\section{Conclusions}

The choice experiment approach in valuing some outputs of the multifunctional farm sector in Cyprus verifies public awareness concerning agriculture's externalities. Cypriots are willing to pay for environmental benefits, through the reduction in pesticide and irrigation water use, for the protection of agricultural cultural heritage and for the continuation of farming on the island. This positive WTP reflects public consent to a shift towards less input-intensive crops which will limit environmental pressures, reduce jobs in the farming sector and improve farm incomes. Farmers who will leave the farming sector, because of this extensification, could be employed in other sectors of the rural economy, which will develop local characteristics formulated by the predominance of agriculture, such as rural landscapes and agricultural cultural heritage. Then, the implementation of such a program could bring about considerable benefits, in terms of non-market goods and services, which overlap income losses from marketed goods.

The results of the analysis can be of use in policy design. The estimated welfare measures verify that agriculture is a multifunctional sector, endowed with environmental and social functions. Therefore, decisions about the cropping pattern, rural development and price policies should always incorporate the values of nonmarketed services provided by the agricultural sector. Special attention needs to be directed to the values of the farm trade, as the continuation of farming on the island is valued by the public, which provides an argument for interventions in the sector.

The results of the analysis verify that the public is in favor of policies that aim at the diversification of the rural economy (Axis III, Reg. (EC) 1698/2005). The analysis has shown that agriculture's externalities provide a wide range of resources that could be developed in this context. The use of existing cultural, environmental and social resources in development programs could produce better results as it reclaims local know-how. In this pattern, agriculture's externalities are resources for sustainable development, as environmental pressures would be mitigated and infrastructure for rural population would be created. The contribution of farming in local economies would be reduced, without however ceasing to perform its environmental and social functions.

Comparisons between the estimated benefits and income losses are not the only criteria for the choice of the proper agricultural system. Other significant factors in the decision making-process are transaction costs, constraints set by EU and local legislation, infrastructures for the rural population and other externalities of agriculture, which have not been included in the experimental design. An integrated approach of multifunctional agriculture could provide estimates of the total economic value of Cypriot agriculture. Furthermore, the formulation of a common valuation framework in other EU countries could provide policy-makers with valuable information in planning the future of the CAP.

\section{Acknowledgements}

The authors acknowledge the financial support of the Cyprus Research Promotion Foundation 


\section{References}

Abler, D. (2003). Multifunctionality, agricultural policy and environmental policy. Agricultural and Resource Economics Review, 33(1), pp. 8-17.

Abou-Ali, H. and Carlsson, F. (2004). Evaluating the welfare effects of improved water quality using the choice experiment method. Working Papers in Economics nr. 131, Department of Economics, Gothenburg University.

Allaire, G. et Dupeuble, T. (2002). "De le multifonctionnalite de 1' activite agricole a la multi-evaluation de la production agricole: vers l' emergence d' un nouveau systeme de competences". Colloque SFER, La Multifonctionnalite de l'Activite Agricole, 21-22 mars 2002, Paris.

Arrow, K., Solow, R., Portney, P., Leamer, E., Radner, R. and Schuman, H. (1993). Contingent Valuation Methodology Report, Report of the NOAA Panel on Contingent Valuation. Federal Resister, 58(10), p. 4602-4614.

Bhat, C.R. (1999). Quasi-random maximum simulated likelihood estimation of the mixed multinomial logit model. Transportation Research, 35B(7), pp. 677-695.

Bhat, C.R. (2000). A multi-level cross-classified model for discrete response variables. Transportation Research, 34B(7), pp. 567-582.

Birol, E., Karousakis, K. and Koundouri, P. (2006). Using a choice experiment to account for preference heterogeneity in wetland attributes: The case of Cheimaditida wetland in Greece. Ecological Economics, 60, pp. 145-156.

Blandford, D. and Boisvert, R.N. (2002). Multifunctional agriculture and domestic/international policy choice. The Estey Centre Journal of International Law and Trade Policy, 3(1), pp. 106-118.

Boody, G., Vondracek, B., Andow, D.A., Krinke, M., Westra, J., Zimmerman, J. and Welle, P. (2005). Multifunctional agriculture in the United States. Bioscience, 55(1), pp. 27-38.

Boxall, P.C., Adamowicz, W.L., Swait, J., Williams, M. and Louviere, J. (1996). A comparison of stated preference methods for environmental valuation. Ecological Economics, 18, pp. 243-253.

Burton, R.O. and Martin, M.A. (1987). Restrictions on herbicide use: An analysis of the economic impacts on US agriculture. North Central Journal of Agricultural Economics, 9(2), pp. 181-194.

Casini, L., Ferrari, S., Lombardi, G., Rambolinaza, M., Sattler, C. and Waarts, Y. (2004). Research report on the analytic multifunctionality framework. Report of the FP6 Research Project MEA-Scope.

Cayre, P., Depigny S. et Michelin, Y. (2004). Multifonctionnalite de 1' agriculture: Quelle motivation de l' agriculteur? Les Cahiers de la Multifonctionnalite, 5, pp. 516.

Christensen, T., Pedersen, A.B., Nielsen, H.O., Morkbak, M.R., Hasler, B. And Denver, S. (2011). Determinants of farmers' willingness to participate in subsidy schemes for pesticide-free buffer zones - A choice experiment study. Ecological Economics, 70, pp. 1558-1564.

Christiadi and Cushing, B. (2007). "Conditional logit, IIA and alternatives for estimating modelsof interstate migration". $46^{\text {th }}$ Annual Meeting of the Southern Regional Science Association, March 29-31 2007, Charleston, SC.

Deverre, C. (2002). "Les nouveaux liens sociaux autour du territoire". Entretiens de Pradel "Agronomes et Territoires", 12-13 Septembre2002, Mirabel. 
Dobbs, T.L. and Pretty, J.N. (2004). Agri-environmental stewardship schemes and "multifunctionality". Review of Agricultural Economics, 26(2), pp. 220-237.

Dwyer, A.C. and Hodge, I. (1996). "Countryside in trust”. Wiley, Chichester.

Fleischer, A. and Tsur, Y. (2000). Measuring the Recreational Value of Agricultural Landscape. European Review of Agricultural Economics, 27(3), pp. 385-398.

Hanemann, W.M. (1984). Welfare evaluations in contingent valuation experiments with discrete responses. American Journal of Agricultural Economics, 66, p. 332341.

Hanemann, W.M. (1989). Welfare evaluations in contingent valuation experiments with discrete response data: Reply. American Journal of Agricultural Economics, 71, p. 1057-1061.

Harvey, D.R. (2003). Agri-environmental relationships and multifunctionality. The World Economy, 26, pp. 705-725.

Hausman, J.A. and McFadden, D. (1984). Specification tests for the multinomial logit model. Econometrica, 52, pp. 1219-1240.

Havlík, P., Veysset, P., Boisson, J.-M., Lherm, M. and Jacquet, F. (2005). Joint production under uncertainty and multifunctionality of agriculture: Policy considerations and applied analysis. European Review of Agricultural Economics, 32(4), pp. 489-515.

Hediger, W. and Lehmann, B. (2003). "Multifunctional agriculture and the preservation of environmental benefits". $25^{\text {th }}$ International Conference of Agricultural Economists, 16-22 August 2003, Durban, South Africa.

Hensher, D.A., Rose, J.M and Greene, W.H. (2005). "Applied Choice Analysis: A Primer". Cambridge University Press.

Hicks, J.R. (1939). "Value and capital: An inquiry into some fundamental principles of economic theory". Oxford: Clarendon Press.

Hitchens, M.T., Thampapillai, D.J. and Sinden, J.A. (1978). The opportunity cost criterion for land allocation. Review of Marketing and Agricultural Economics, 46, pp. 275-293.

Jervell, A.M. and Jolly, D.A. (2003). Beyond food: Towards a multifunctional agriculture. Norwegian Agricultural Economics Research Institute, Oslo, Norway.

Kallas, Z., Gomez-Limon, J.A. and Arriaza, M. (2007). Joint valuation of noncommodity outputs of multifunctional agriculture: A choice experiment approach. Agricultural Economics, 36(3), pp. 405-419.

Krinsky, I. and Robb, A.L. (1986). On approximating the statistical properties of elasticities. Review of Economics and Statistics, 68, pp. 715-719.

Lancaster, K. (1966). A new approach to consumer theory. Journal of Political Economy, 74(2), pp. 132-157.

Lindland, J. (1998). Non-trade concerns in a multifunctional agriculture: Implications for agricultural policy and the Multilateral Trading System. $\mathrm{COM} / \mathrm{GR} / \mathrm{CA} / \mathrm{TD} / \mathrm{TC} / \mathrm{WS}(98) 124$.

Louviere, J.J., Hensher, D. and Swait, J. (2000). "Stated Choice Methods: Analysis and Applications in Marketing, Transportation and Environmental Valuation". Cambridge University Press.

Lowe, P., Buller, H. and Ward, N. (2002). Setting the next agenda?: British and French approaches to the Second Pillar of the Common Agricultural Policy. Journal of Rural Studies, 18, pp. 1-17. 
Lusk, J.L., Roosen, J. and Fox, J.A. (2003). Demand for beef from cattle administered growth hormones or fed genetically modified corn: A comparison of consumers in France, Germany, the United Kingdom and the United States. American Journal of Agricultural Economics, 85(1), pp. 16-29.

McFadden, D. (1973). Conditional logit analysis of qualitative choice behaviour. In: Zarembka, P. (Ed.), "Frontiers in Econometrics", Academic Press, New York and London, pp. 105-142.

Mitchell, R.C. and Carson, R.T. (1989). Using surveys to value public goods: The contingent valuation method. Resources for the Future, Washington, DC.

Morey, E.R. and Rossmann, K.G. (2003). Using stated preference questions to investigate variations in willingness to pay for preserving marble monuments: Classic heterogeneity, random parameters and mixture models. Journal of Cultural Economics, 27(4), pp. 215-229.

OECD (2001). Multifunctionality: Towards an analytical framework. OECD, Paris,. OECD (2003). Multifunctionality: The policy implications. OECD, Paris.

Paarlberg, P.L., Bredahl, M. and Lee, J.G. (2002). Multifunctionality and agricultural trade negotiations. Review of Agricultural Economics, 24(2), pp. 322-335.

Peterson, J.M., Boisvert, R.N. and de Gorter, H. (2002). Environmental policies for a multifunctional agricultural sector in open economies. European Review of Agricultural Economics, 29(4), pp. 423-443.

Potter, C. (2004). Multifunctionality as an agricultural and rural policy concept. In: Brouwer, F. (Ed.), "Sustaining Agriculture and the Rural Environment: Governance, Policy, and Multifunctionality", Edward Elgar, Cheltenham, UK, pp. 15-35.

Potter, C. and Burney, J. (2002). Agricultural multifunctionality and the WTO: Legitimate non-trade concern or disguised protectionism?. Journal of Rural Studies, 18, pp. 35-47.

Pretty, J.N., Brett, C., Gee, D., Hine, R.E., Mason, C.F., Morison, J.I.L., Raven, H., Rayment, M.D. and van der Bijl, G. (2000). An assessment of the total external costs of UK agriculture. Agricultural Systems, 65, pp. 113-136.

Ragkos, A., Theodoridis, A., Socratous, S., Mavrommatis, G. and Psychoudakis, A. (2010). Alternative cropping patterns of Cypriot farming and their impact on the level of externalities. In: $3^{\text {rd }}$ Volume of scientific papers of Hellenic Association of ICT in Agriculture, Food and Environment (HAICTA).

Randall, A. (2002). Valuing the outputs of multifunctional agriculture. European Review of Agricultural Economics, 29(3), pp. 289-308.

Revelt, D. and Train, K. (1998). Mixed logit with repeated choices: Households' choice of appliance efficiency level. Review of Economics and Statistics, 53, pp. 647657.

Romstad, E. (2004a). Methodologies for agri-environmental policy design. In: Brouwer, F. (Ed.), "Sustaining Agriculture and the Rural Environment: Governance, Policy, and Multifunctionality", Edward Elgar, Cheltenham, UK.

Romstad, E. (2004b). Multifunctional agriculture - focus and resource allocation. Discussion Paper, Department of Economics and Resource Management Agricultural University of Norway.

Streeter, D.H. (1988). Farmland preservation: The role of off-farm income. Landscape and Urban Planning, 16, pp. 357-364. 
Sumner, D.A. (1991). Useful directions for research on multiple job-holding among farm families. In: Hallberg, M.C., Findeis, J.L. and Lass, D.A. (Eds.), "Multiple job holdings among farm families", Iowa State University Press, Ames, Iowa, pp. 149160.

Thampapillai, D.J. and Sinden, J.A. (1979). Trade-offs for multiple objective planning through linear programming. Water Resource Research, 15, pp. 1028-1033. Train, K. (2003). “Discrete Choice Methods with Simulation”. Cambridge University Press.

Travisi, C.M. and Nijkamp, P. (2008). Valuing environmental and health risk in agriculture: A choice experiment approach to pesticides in Italy. Ecological Economics, 67, pp. 598-607.

Vermersch, D. (2001). Multifunctionality: Applying the OECD framework. A review of literature in France. Directorate for Food, Agriculture and Fisheries, OECD.

de Vries, B. (2000). Multifunctional agriculture in the international context: A review. The Land Stewardship Project.

Yrjola, T. and Kola, J. (2004). Consumer preferences regarding multifunctional agriculture. International Food and Agribusiness Management Review, 7(1), pp. 7890 . 